\title{
Giant Cell Tumor of Bone: 6 Years Institutional Retrospective Review
}

\author{
Nadeem Ali ${ }^{1}$ Dar Ghulam Nabi ${ }^{1} \quad$ Azad Ahmad Shah ${ }^{1} \quad$ Altaf Ahmad Kawoosa ${ }^{1} \quad$ Mohammad Umar Mumtaz ${ }^{1}$ \\ ${ }^{1}$ Department of Orthopaedics, Government Medical College (GMC) \\ Srinagar, Srinagar, Jammu and Kashmir, India \\ Address for correspondence Nadeem Ali, MS, Department of \\ Orthopaedics, Government Medical College (GMC) Srinagar, \\ Mughal Mohalla, Lalbazar, Srinagar 190023, Jammu and Kashmir, \\ India (e-mail: drnadeeem@gmail.com).
}

Int J Recent Surg Med Sci 2020;6:12-17

\begin{abstract}
Introduction Surgery is the cornerstone for the management of giant cell tumors (GCTs). There are no definite guidelines for the management. The purpose of this series was to study the patient demography and results of the surgical intervention for skeletal GCTs in our population.

Materials and Methods All the histologically diagnosed cases of GCT of bone from year 2012 to 2018 were retrospectively analyzed for patient demographics, site, and grade of the lesion, type of biopsy taken (if any), nature of surgical intervention, and final outcome with respect to complications.

Results Seventeen cases of skeletal GCT were diagnosed on histopathology. The mean age at presentation was $31.5 \pm 10.9$ years with females affected 1.4 times more. Proximal tibia was the most common site $(29.4 \%)$ followed by distal radius and distal femur in that order. About $58.8 \%$ of the lesions were of Campanacci grade 2 and remaining were grade 3 lesions. Ten patients had extended curettage, five had en bloc resection, and one had amputation as the primary treatment. Twenty percent patients

Keywords

- curettage

- giant cell

- epiphysis

- GCT

- polymethyl

methacrylate $(n=3)$ had local recurrence of the pathology and one patient developed distant recurrence (lung metastasis).

Conclusion Proximal tibia followed by distal radius was the most common site of GCT in our population. The tumor behavior and recurrence cannot be predicted with any grading system. The goal should be salvage of the joint by intralesional curettage, with resection reserved for distal radius GCTs, cases with extensive soft tissue extension or those with destruction of the articular cartilage and joint involvement.
\end{abstract}

\section{Introduction}

Giant cell tumor (GCT) of bone is a relatively common bone tumor accounting for 4 to $10 \%$ of all bone tumors. Though classified as a benign tumor, it has local aggressiveness and propensity for distant metastasis. It constitutes around $20 \%$ of benign bone tumors and the incidence of metastasis has been estimated to be 1 to $6 \%$, with lungs being the most common site. ${ }^{1,2}$ The tumor arises from the epiphysis after skeletal maturity and thus radiologically presents as an epiphysiometaphyseal lesion. ${ }^{3}$ It is classically seen in third and fourth decade of life with slight propensity for females. ${ }^{1,4}$ The treatment of GCT has evolved over years with extended intralesional curettage using adjuvant therapy, to kill the residual tumor cells in the wall of the cavity, as the gold standard. GCT differs from other benign tumors in its local aggressiveness, recurrence, and its epiphysiometaphyseal location with its margins usually within $1 \mathrm{~cm}$ from the subchondral bone that may make joint salvage difficult. ${ }^{1,5,6}$ Besides at present there are no clear-cut guidelines pertaining to surgical treatment of these lesions.

The purpose of this study was to review the demographic features of the patients and outcome of various surgical techniques for GCT of the bone at a tertiary care center. published online

May 23, 2020
DOI https://doi.org/

10.1055/s-0040-1712861

ISSN 2455-7420.
(C)2020 Medical and Surgical Update Society
License terms

(ㅇ) (1) $\ominus \circledast$ 


\section{Materials and Methods}

This retrospective study was conducted in one of the orthopaedic units of a tertiary care center and all the histopathologically diagnosed cases of GCT of bone from 2012 to 2018 were included in this study. Demographic data of all the patients, clinical presentation including presence of a pathological fracture, site of the lesion, Campanacci grade of the lesion, any evidence of distant metastasis, type of biopsy taken for histopathological diagnosis, nature of surgical procedure performed, follow-up duration after the surgical procedure, complications, and their management were recorded. With respect to outcome and complications, only those patients were included who had a minimum postsurgical follow-up of 2 years.

\section{Results}

A total of 17 cases of GCT of bone were diagnosed over a period of 6 years from 2012 to 2018. Age of the patients ranged from 18 to 52 years with a mean of $31.5 \pm 10.9$ years. Majority of the patients (47\%) were in third decade of their life. Pathology was more common in females with a male to female ratio of 1:1.4. Proximal tibia was the most common site affected, seen in 5 (29.4\%) cases followed by distal end of radius in three (17.6\%) cases. About $47.1 \%$ of the lesions were located around the knee joint ( - Table 1 ).

The most common clinical symptom was pain seen in all the 17 patients followed by local swelling in 7 (41.2\%) patients. Ten $(58.8 \%)$ patients had some degree of subjective and/or objective restriction of the adjacent joint function. None of the patients had a pathological fracture at presentation. As per Campanacci radiological grading, 10 (58.8\%) lesions were of grade 2 and remaining 7 (41.2\%) were of grade 3 (-Table 1). None had radiological evidence of distant metastasis. Computed tomography and/or magnetic resonance imaging of the lesion showed extension of the lesion within $1 \mathrm{~cm}$ from the subchondral bone in all the cases and cortical breach with some degree of soft tissue extension was seen in seven patients. One of these patients, with lesion of the distal humerus, had extensive soft tissue invasion. Before surgical intervention, diagnostic biopsy was taken in 13 patients. Open incision biopsy was obtained in three patients and image-guided core needle biopsy in ten patients.

Sixteen patients underwent surgical intervention. One patient with pelvic GCT was referred to higher center. Ten (62.5\%) patients had intralesional extended curettage using an adjuvant. In four patients a combination of electrocoagulation and bone cement, in three patients electrocoagulation, in two patients bone cement, and in one patient a combination of electrocoagulation and hydrogen peroxide was used as adjuvant. Three patients who had involvement of subchondral bone by the lesion and in whom bone cement was used, sandwich technique using cancellous bone graft, gel foam, and bone cement was used ( - Fig. 1). Stabilization using plates was required in two cases of extended curettage, while one patient required placement of mantle screws
(-Fig. 1). Five (37.5\%) patients required en bloc resection of the pathological bone. Biological reconstruction after en bloc resection using an allograft (fibula) was carried out in four patients, while one patient who had excision of proximal fibula did not require such reconstruction. In the reconstruction group, two patients (GCT of distal radius) had reconstruction arthroplasty with proximal fibula of opposite side and other two patients (one with GCT distal radius and one with GCT of distal tibia) had reconstruction and fusion with a simple fibular strut graft. One patient with GCT of distal humerus and extensive soft tissue extension was managed by transhumeral amputation.

One patient with GCT of distal tibia was lost to follow-up at 1 year. The follow-up of the remaining 15 patients ranged from 1 year and 4 months to 4 years and 2 months with an average follow-up duration of 2 years and 8 months. Recurrence of the pathology was seen in four (16\%) patients after the surgical intervention. One of these patients had distant recurrence in the form of pulmonary metastasis and the patient died at 1 year and 4 months follow-up. Patient with recurrence at distal ulna was managed by en bloc resection of distal ulna ( -Fig. 2). Other patient with soft tissue recurrence at distal radius underwent wide marginal excision of the soft tissue tumor. Patient with recurrence at proximal tibia presented with a fungating growth and had transfemoral amputation for the local recurrence. All the patients with local recurrence were Campanacci grade 2 and one with lung metastasis was a grade 3 lesion. Only one patient (GCT distal radius) had infection and loss of fixation in the postoperative period that required debridement of the fibular allograft and subsequently ulnocarpal fusion. One patient with proximal fibular GCT who had excision of the proximal fibula developed neuropraxia of the common peroneal nerve (foot drop) that recovered completely in 5 months. One patient with proximal tibial GCT with involvement of subchondral bone (managed by sandwich technique) had valgus instability, lateral compartment pain, and arthritis. This was due to change in contour of the lateral compartment articular cartilage secondary to involvement of subchondral bone and subsequent depression before surgical intervention. Postoperatively, it was managed by a knee brace.

\section{Discussion}

GCT is a relatively common primary bone tumor that constitutes around $20 \%$ of the benign bone tumors. ${ }^{1}$ Characteristic feature is appearance after skeletal maturity with peak incidence in third and fourth decade of life. ${ }^{4,7}$ In most of the studies from China and Japan, the mean age at presentation ranges from 30.5 to 35.7 years. ${ }^{8}$ Similarly, Elshenawy et al in their institutional review of 42 patients had a mean presenting age of 32.3 years. ${ }^{9}$ Our mean presenting age of 31.5 years is consistent with these studies. As per world literature, more than $50 \%$ of the patients are in third and fourth decade of their life that is comparable to our $64.7 \%{ }^{4}$ We had no case of GCT in skeletally immature and elderly patients. It is very rare but has been reported in the literature. ${ }^{10,11}$ There is slight female predilection with a female to male ratio ranging from 1.1: 1 to $1.6: 1$ in the literature and ratio of 1.42: 1 in our study falls within this range. ${ }^{1,9}$ 
Table 1 Demographic and clinical details of the patients

\begin{tabular}{|c|c|c|c|c|c|c|}
\hline Age/sex & Site & C. grade & Primary procedure & Hardware & Complications & Secondary procedure \\
\hline $52 / F$ & Distal radius (L) & 3 & $\begin{array}{l}\text { EBR and } \\
\text { reconstruction } \\
\text { arthroplasty with } \\
\text { proximal fibular } \\
\text { autograft }\end{array}$ & Plate fixation & $\begin{array}{l}\text { Infection and graft } \\
\text { sequestration }\end{array}$ & $\begin{array}{l}\text { Removal of graft and } \\
\text { plate f/b ulnocarpal } \\
\text { fusion }\end{array}$ \\
\hline $22 / M$ & Talus (R) & 2 & $\mathrm{EC}$ (E coag) and BG & - & - & - \\
\hline $35 / M$ & Proximal tibia (R) & 2 & $\mathrm{EC}$ with $\mathrm{BC}$ & - & $\begin{array}{l}\text { Recurrence (1 and half } \\
\text { years) }\end{array}$ & $\begin{array}{l}\text { Transfemoral } \\
\text { amputation }\end{array}$ \\
\hline $22 / F$ & Distal tibia (R) & 3 & $\begin{array}{l}\text { EBR and fibular auto- } \\
\text { graft and cancellous } \\
\text { BG reconstruction }\end{array}$ & Screw fixation & Lost in follow-up & - \\
\hline $24 / F$ & Proximal tibia (L) & 2 & $\begin{array}{l}\text { EC (E coag and } \\
\text { BC) (sandwich } \\
\text { technique) }\end{array}$ & Mantle screws & - & - \\
\hline $28 / \mathrm{M}$ & Distal ulna (R) & 2 & $\begin{array}{l}\text { EC (E coag and } \\
\text { hydrogen peroxide) } \\
\text { and BG }\end{array}$ & - & Recurrence (1 year) & EBR distal ulna \\
\hline $29 / F$ & Distal radius $(\mathrm{L})$ & 2 & $\begin{array}{l}\text { EBR and reconstruc- } \\
\text { tion arthroplasty } \\
\text { with proximal fibular } \\
\text { autograft }\end{array}$ & Plate fixation & - & - \\
\hline $23 / F$ & Proximal tibia (L) & 3 & $\begin{array}{l}\text { Resection of soft } \\
\text { tissue extension and } \\
\text { EC (E coag and } B C)\end{array}$ & Plating (two) & - & - \\
\hline $45 / F$ & Proximal tibia (R) & 2 & $\begin{array}{l}\text { EC (E coag and } \\
\text { BC) (sandwich } \\
\text { technique) }\end{array}$ & - & $\begin{array}{l}\text { Lateral compartment } \\
\text { arthritis }\end{array}$ & - \\
\hline $24 / F$ & Proximal tibia (L) & 3 & $\begin{array}{l}\text { Fibular head } \\
\text { excision, resection of } \\
\text { soft tissue extension } \\
\text { and EC (E coag) and } \\
\text { BG }\end{array}$ & - & - & - \\
\hline $18 / \mathrm{F}$ & $\begin{array}{l}\text { Proximal } \\
\text { Humerus (R) }\end{array}$ & 2 & $\mathrm{EC}$ with $\mathrm{BC}$ & - & - & - \\
\hline $19 / F$ & Distal femur (R) & 3 & $\begin{array}{l}\text { EC (E coag) and can- } \\
\text { cellous and fibular } \\
\text { strut BG }\end{array}$ & Medial plating & - & - \\
\hline $36 / F$ & Distal femur (L) & 2 & $\begin{array}{l}\text { EC (E coag and } \\
\text { BC) (sandwich } \\
\text { technique) }\end{array}$ & - & - & - \\
\hline $42 / F$ & Distal radius ( $\mathrm{R})$ & 2 & $\begin{array}{l}\text { EBR and } \\
\text { reconstruction } \\
\text { using fibular strut } \\
\text { autograft (wrist } \\
\text { fusion) }\end{array}$ & $\begin{array}{l}\text { Wrist } \\
\text { arthodesis } \\
\text { plate }\end{array}$ & $\begin{array}{l}\text { Local soft tissue } \\
\text { recurrence }\end{array}$ & $\begin{array}{l}\text { Resection of soft tissue } \\
\text { recurrence }\end{array}$ \\
\hline 29/M & Fibular head (L) & 2 & $\begin{array}{l}\text { Proximal fibular } \\
\text { excision }\end{array}$ & - & $\begin{array}{l}\text { Common peroneal } \\
\text { nerve neuropraxia }\end{array}$ & - \\
\hline $36 / M$ & $\begin{array}{l}\text { Distal humerus } \\
\text { (L) }\end{array}$ & 3 & $\begin{array}{l}\text { Transhumeral } \\
\text { amputation }\end{array}$ & - & Lung metastasis & - \\
\hline $52 / M$ & Pelvis (L) & 3 & $\begin{array}{l}\text { Referred to higher } \\
\text { center }\end{array}$ & - & - & - \\
\hline
\end{tabular}

Abbreviations: BG, bone grafting; C. grade, Campanacci grade; E coag, electrocoagulation; EBR, en bloc resection; EC, extended curettage; f/b, followed by; F, female; L, left; $M$, male; $R$, right.

Historically, GCT is believed to arise from the epiphysis and presents as an epiphysiometaphyseal lesion with articular cartilage and the joint being resistant to invasion. ${ }^{11,12}$ Murphey et al reported 84 to $99 \%$ of the lesions extend to locations within $1 \mathrm{~cm}$ of the subarticular bone. ${ }^{5}$ All our cases had extension of the lesion within $1 \mathrm{~cm}$ of the subchondral bone. GCTs have also been reported in patients with open epiphyseal growth plates and these are metaphyseal 

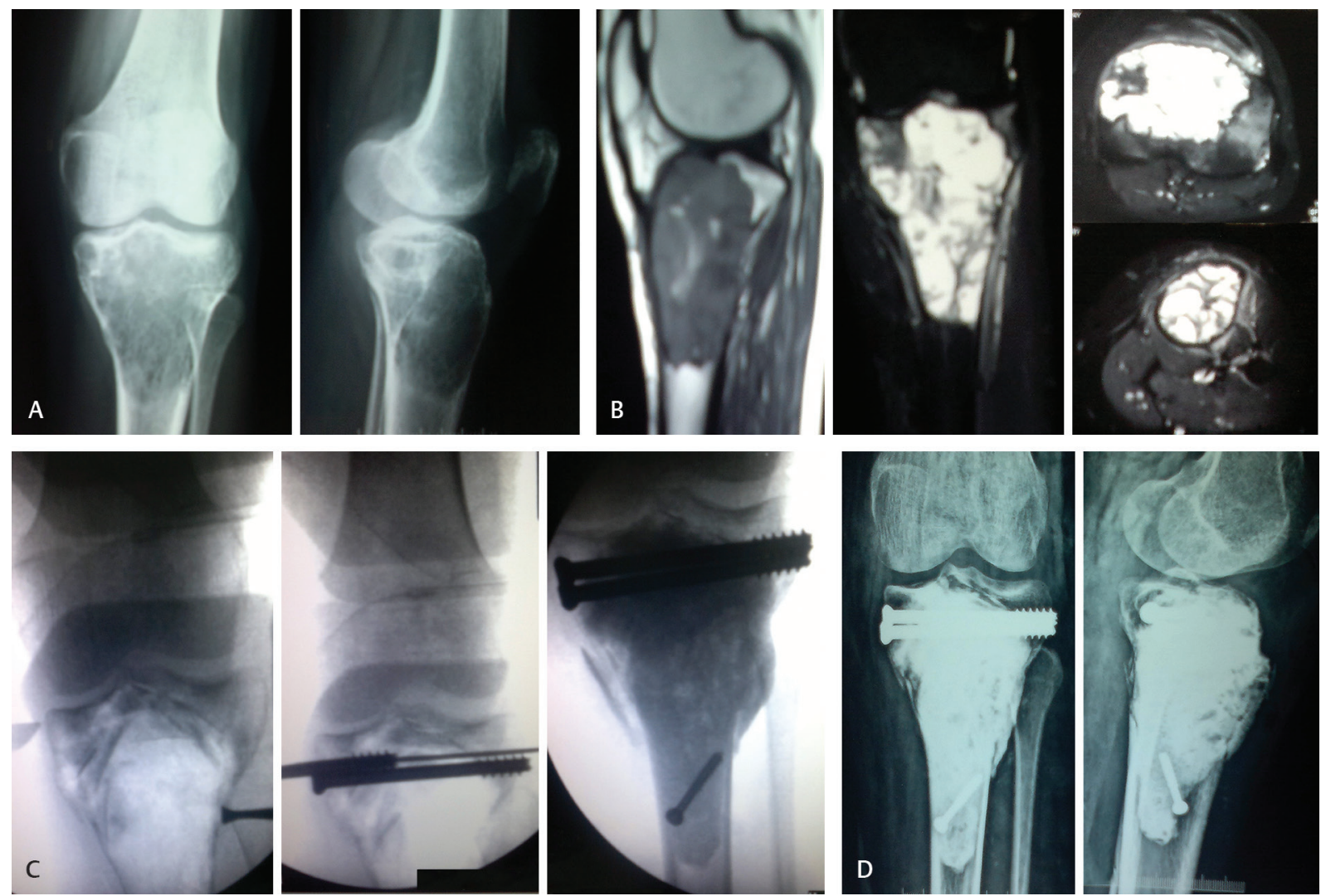

Fig. 1 Giant cell tumor of proximal tibia. (A) Radiographs showing lytic lesion. (B) Magnetic resonance imaging. (C) Intraoperative fluoroscopy showing placement of bone graft under subchondral bone, use of mantle screws, and filling the cavity with polymethyl methacrylate (sandwich technique). (D) Postoperative radiograph.
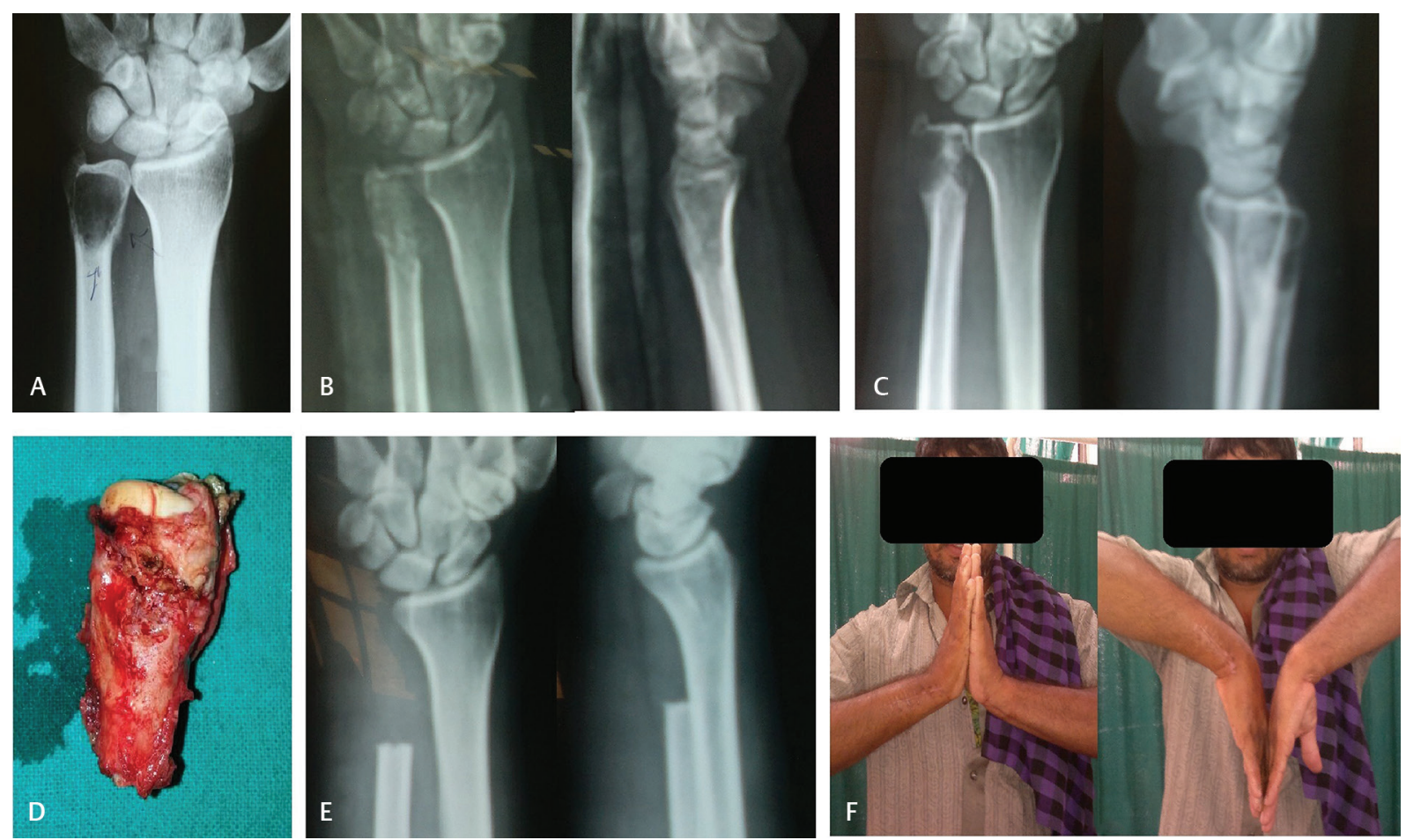

Fig. 2 Giant cell tumor of distal ulna. (A) Radiograph showing lytic lesion. (B) Postoperative radiograph after extended curettage and bone grafting. (C) Radiograph showing recurrence of the pathology. (D) En bloc resection of distal ulnar specimen. (E) Radiographs after resection. (F) Clinical photographs showing final function. 
in location with growth plate acting as a barrier to tumor growth that suggests metaphyseal origin of this tumor. ${ }^{13}$ Most commonly GCT is located around the knee joint (50 to $65 \%$ of all the cases). In our series too, most of the lesions were around the knee joint (47.1\%). Distal femur is the most common site followed by proximal tibia and distal radius, but in our series proximal tibia was the most common site involved followed by distal radius. ${ }^{1}$ Çomunoğlu et al also in their institutional experience of 120 cases had proximal tibia followed by distal femur as the most common site of GCT. ${ }^{14}$ Rare sites include spine, small bones of hand and feet, patella, distal ulna. ${ }^{1,15}$ We had one case each involving talus and distal ulna. Pain is the most common presentation of GCT that results from bone insufficiency and destruction. A palpable bump may be a presentation in case of soft tissue extension through a cortical breech. Interference with adjacent joint function is common. Pathological fracture with acute onset pain is a presentation in 10 to $12 \%$ of GCTs and is an indicator of aggressive disease with poor prognosis with respect to recurrence and metastasis. ${ }^{12,16}$ None of our patients presented with a pathological fracture. GCTs have been classified histologically (Jaffe et al) as well as radiologically (Enneking et al and Campanacci et al). Campanacci et al graded GCT into three grades and is a preferred grading system for GCTs. However, none of the classification systems is helpful in formulating guidelines for surgical treatment. And no correlation exists between grade of the tumor and incidence of local recurrence and distant metastasis. ${ }^{1,17-19}$ All the patients in our series with local recurrence were of Campanacci grade 2 and no patient with grade 3 lesion had local recurrence except one patient who had lung metastasis.

Although labeled as a benign tumor, the treatment of GCT is always surgical because of its local aggressiveness and tendency to invade surrounding tissues. ${ }^{1,9}$ Juxta-articular location makes treatment difficult and challenging. Intralesional approach to tumor preserves the joint function at the cost of risk of local recurrence. En bloc resection of the lesion has the advantage of decreased risk of local recurrence with a recurrence-free survival ranging from 84 to $100 \%$, but with added morbidity and loss of joint function. ${ }^{12}$ The results of curettage have improved with the advent of extended curettage that uses adjuvants like liquid nitrogen, phenol, alcohol, hydrogen peroxide, zinc chloride, electrocoagulation, polymethyl methacrylate, and locally delivered chemotherapy. ${ }^{1,20}$ The aim of extended curettage is to take care of microscopic tumor remnants in the walls, after the cavity is curetted out thoroughly. In literature, the incidence of local recurrence after simple curettage and bone grafting has been reported to be between 25 and 50\% that has been dramatically reduced to 6 to $25 \%$ with the use of adjuvants. ${ }^{12}$ In our retrospective study, $20 \%$ of patients with extended curettage had a local recurrence. One patient (20\%) in the resection group had a local recurrence too. One of the patients managed with transhumeral amputation presented with distant recurrence in the lungs. Metastasis to lungs despite a radical excision of the pathology and mortality secondary to pulmonary metastasis within 1 year and 4 months is suggestive of aggressive nature of the GCT in this case. The pulmonary metastatic lesions are usually slowly growing and amenable to resection and have been termed as benign pulmonary implants and the prognosis is favorable in more than $70 \%$. In some cases, the pulmonary lesions resolve spontaneously but some may succumb to multiple pulmonary lesions as happened in our case. ${ }^{1,21}$ Jamshidi et al in their comparison of en bloc resection versus curettage and bone grafting for GCT of distal ulna recommended resection for grade 3 tumors and curettage for lower grade tumours. ${ }^{15}$ But some surgeons recommend excision for lesions of distal ulna, proximal fibula, proximal radius, coccyx, and saccrum. ${ }^{12,22}$ There was no re-recurrence in our patient after the recurrence at distal ulna (post curettage) was managed by en bloc excision. The surgical approach for distal radius GCT has been controversial as the distal radius lesions are considered aggressive with high chances of local recurrence. ${ }^{2,23}$ Pazionis et al in their meta-analysis on distal radial GCTs concluded local recurrence was three times more with intralesional curettage as compared to wide excision. ${ }^{24}$ Considering these facts we prefer wide excision over curettage in distal radial GCTs. In cases where only thin rim of subchondral bone and overlying cartilage is preserved, the exothermic reaction from cementing can damage the joint cartilage and lead to subsequent arthritis. This harmful effect of bone cement can be prevented by using sandwich technique where a layer of bone graft followed by a gel foam layer is packed under the subchondral bone before pushing bone cement into the void. ${ }^{25}$ We also prefer this technique when only a thin rim of subchondral bone is preserved and bone cement is used.

\section{Conclusion}

The demographics of our patients and the tumor behavior was comparable to the world literature except for proximal tibia being the most common site of involvement. The choice of surgical technique depends on several factors with joint salvage using extended curettage as the gold standard. Resection of the bone with reconstruction should be reserved for GCT of the distal radius, and cases with articular cartilage and extensive soft tissue involvement.

\section{Conflict of Interest}

None declared.

\section{References}

1 Mavrogenis AF, Igoumenou VG, Megaloikonomos PD, Panagopoulos GN, Papagelopoulos PJ, Soucacos PN. Giant cell tumor of bone revisited. SICOT J 2017;3:54

2 Puri A, Agarwal M. Treatment of giant cell tumor of bone: current concepts. Indian J Orthop 2007;41(2):101-108

3 Purohit S, Pardiwala DN. Imaging of giant cell tumor of bone. Indian J Orthop 2007;41(2):91-96

4 McGrath PJ. Giant-cell tumour of bone: an analysis of fifty-two cases. J Bone Joint Surg Br 1972;54(2):216-229

5 Murphey MD, Nomikos GC, Flemming DJ, Gannon FH, Temple HT, Kransdorf MJ. From the archives of AFIP. Imaging of giant cell tumor and giant cell reparative granuloma of bone: radiologic-pathologic correlation. Radiographics 2001;21(5):1283-1309 
6 Panchwagh Y, Puri A, Agarwal M, Anchan C, Shah M. Giant cell tumor - distal end radius: do we know the answer? Indian J Orthop 2007;41(2):139-145

7 Chakarun CJ, Forrester DM, Gottsegen CJ. Patel DB, White EA, Matcuk GR Jr. Giant cell tumor of bone: review, mimics, and new developments in treatment. Radiographics 2013;33(1):197-211

8 Liede A, Hernandez RK, Tang ET, et al. Epidemiology of benign giant cell tumor of bone in the Chinese population. J Bone Oncol 2018;12:96-100

9 Elshenawy MA, Badran AA, Memon MA, Elshentenawy AM, Elhassan T. Outcome of treatment in giant cell tumors of bones: a single institutional retrospective review. Resum Oncol 2019;15(1):9-14

10 Kransdorf MJ, Sweet DE, Buetow PC. Giudici MA, Moser RP Jr. Giant cell tumor in skeletally immature patients. Radiology 1992;184(1):233-237

11 Broehm CJ, Inwards CY, Al-Ibraheemi A, et al. Giant cell tumor of bone in patients 55 years and older: a study of 34 patients. Am J Clin Pathol 2018;149(3):222-233

12 Sobti A, Agrawal P, Agarwala S, Agarwal M. Giant cell tumor of bone - an overview. Arch Bone Jt Surg 2016;4(1):2-9

13 Futamura N, Urakawa H, Tsukushi S, et al. Giant cell tumor of bone arising in long bones possibly originates from the metaphyseal region. Oncol Lett 2016;11(4):2629-2634

14 Çomunoğlu N, Kepil N, Dervişoğlu S. Histopathology of giant cell tumors of the bone: with special emphasis on fibrohistiocytic and aneurysmal bone cyst like components. Acta Orthop Traumatol Turc 2019;53(1):35-39

15 Jamshidi K, Bahrabadi M, Bagherifard A, Mohamadpour M. Surgical treatment outcome of giant cell tumor of distal ulna: en bloc resection vs. curettage and bone graft. Med J Islam Repub Iran 2018;32:44
16 Turcotte RE. Giant cell tumor of bone. Orthop Clin North Am 2006;37(1):35-51

17 Jaffe HL, Lichtenstein L, Portis RB. Giant cell tumor of bone. Its pathologic appearance, grading, supposed variants and treatment. Arch Pathol (Chic) 1940;30(3):993-1031

18 Campanacci M, Baldini N, Boriani S, Sudanese A. Giant-cell tumor of bone. J Bone Joint Surg Am 1987;69(1):106-114

19 Enneking WF, Spanier SS, Goodman MA. A system for the surgical staging of musculoskeletal sarcoma. 1980. Clin Orthop Relat Res 2003;(415):4-18

20 Saibaba B, Chouhan DK, Kumar V, Dhillon MS, Rajoli SR. Curettage and reconstruction by the sandwich technique for giant cell tumours around the knee. J Orthop Surg (Hong Kong) 2014;22(3):351-355

21 Dominkus M, Ruggieri P, Bertoni F, et al. Histologically verified lung metastases in benign giant cell tumours-14 cases from a single institution. Int Orthop 2006;30(6):499-504

22 Vanni D, Pantalone A, Andreoli E, Caldora P, Salini V. Giant cell tumor of the distal ulna: a case report. J Med Case Reports 2012;6:143

23 Saini R, Bali K, Bachhal V, Mootha AK, Dhillon MS, Gill SS. En bloc excision and autogenous fibular reconstruction for aggressive giant cell tumor of distal radius: a report of 12 cases and review of literature. J Orthop Surg Res 2011;6:14

24 Pazionis TJ, Alradwan H, Deheshi BM, Turcotte R, Farrokhyar F, Ghert M. A systematic review and meta-analysis of en-bloc vs intralesional resection for giant cell tumor of bone of the distal radius. Open Orthop J 2013;7:103-108

25 Campanacci M, Capanna R, Fabbri N, Bettelli G. Curettage of giant cell tumor of bone. Reconstruction with subchondral grafts and cement. Chir Organi Mov 1990;75(1(Suppl):212-213 